\title{
Population structure and genetic diversity in the invasive freshwater snail Galba schirazensis (Lymnaeidae)
}

\begin{tabular}{|c|c|}
\hline Journal: & Canadian Journal of Zoology \\
\hline Manuscript ID & cjz-2016-0319.R1 \\
\hline Manuscript Type: & Article \\
\hline Date Submitted by the Author: & 01-Jun-2017 \\
\hline Complete List of Authors: & $\begin{array}{l}\text { Lounnas, Manon; Institut de recherche pour le developpement France- } \\
\text { Sud, MIVEGEC; Universite de Montpellier, Enseignement Biologie Ecologie } \\
\text { Correa, Ana; Institut de recherche pour le developpement France- } \\
\text { Sud, MIVEGEC } \\
\text { Alda, Pilar; Institut de recherche pour le developpement France-Sud, } \\
\text { Laboratoire MIVEGEC; Consejo Nacional de Investigaciones Cientificas y } \\
\text { Tecnicas, Centro de Estudios Parasitológicos y de Vectores (CEPAVE) } \\
\text { David, Patrice; Centre d'Ecologie Fonctionnelle et d'Evolution } \\
\text { Dubois, Marie-Pierre; Centre dEcologie Fonctionnelle et Evolutive } \\
\text { Calvopina, Manuel; Universidad Central del Ecuador, Carrera de Medicina, } \\
\text { Facultad de Ciencias Médicas } \\
\text { Caron, Yannick; Universite de Liege Faculte de Medecine Veterinaire, } \\
\text { Research Unit in Parasitology and Parasitic Diseases, Fundamental and } \\
\text { Applied Research for Animals \& Health (FARAH) } \\
\text { Celi-Erazo, Maritza; Universidad Central del Ecuador, CIZ } \\
\text { Bui, Dung; Universite de Liege Faculte de Medecine Veterinaire, Research } \\
\text { Unit in Parasitology and Parasitic Diseases, Fundamental and Applied } \\
\text { Research for Animals \& Health (FARAH) } \\
\text { Jarne, Philippe; Centre dEcologie Fonctionnelle et Evolutive } \\
\text { Loker, Eric; University of New Mexico , Biology } \\
\text { Noya, Oscar; Instituto de Altos Estudios "Dr. Arnoldo Gabaldón", Centro } \\
\text { para Estudios Sobre Malaria; Instituto Nacional de Higiene "Rafael Rangel" } \\
\text { del Ministerio del Poder Popular para la Salud y Sección de Biohelmintiasis; } \\
\text { Instituto de Medicina Tropical, Facultad de Medicina, Universidad Central } \\
\text { de Venezuela } \\
\text { Rodríguez-Hidalgo, Richar; Universidad Central del Ecuador, Facultad de } \\
\text { Medicina Veterinaria y Zootecnia; Universidad Central del Ecuador, CIZ } \\
\text { Toty, Céline; Institut de recherche pour le developpement France- } \\
\text { Sud, MIVEGEC } \\
\text { Uribe, Nelson; Universidad Industrial de Santander, Escuela de } \\
\text { Bacteriología y Laboratorio Clínico, Facultad de Salud } \\
\text { Pointier, Jean-Pierre; USR 3278 CNRS-EPHE, CRIOBE Université de } \\
\text { Perpignan } \\
\text { Hurtrez-Boussès, Sylvie; Universite de Montpellier, Enseignement Biologie } \\
\text { Ecologie }\end{array}$ \\
\hline Keyword: & $\begin{array}{l}\text { lymnaeids, Lymnaea, Galba schirazensis, Galba truncatula, vector, } \\
\text { microsatellites, selfing }\end{array}$ \\
\hline
\end{tabular}




\section{SCHOLARONE ${ }^{\text {m }}$}

Manuscripts 
Article submission, Canadian Journal of Zoology

\title{
Population structure and genetic diversity in the invasive freshwater snail
}

\section{Galba schirazensis (Lymnaeidae)}

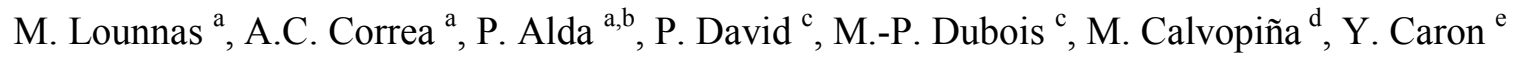 \\ M. Celi-Erazo ${ }^{\text {f }}$, B.T. Dung ${ }^{\text {e }}$, P. Jarne ${ }^{\text {c }}$, E.S. Loker ${ }^{\mathrm{g}}$, O. Noya ${ }^{\mathrm{h}}, \mathrm{R}$. Rodríguez-Hidalgo ${ }^{\mathrm{fi}}, \mathrm{C}$. \\ Toty $^{a}$, N. Uribe ${ }^{\mathrm{j}}$, J.-P. Pointier ${ }^{\mathrm{k}}$, S. Hurtrez-Boussès ${ }^{\mathrm{a}, 1}$
}

${ }^{\text {a }}$ MIVEGEC, UMR UM - CNRS 5290 - IRD 224 Maladies Infectieuses et Vecteurs: Ecologie, Génétique, Evolution et Contrôle, Centre IRD, BP 64501, 34394 Montpellier Cedex 5, France

${ }^{\mathrm{b}}$ Centro de Estudios Parasitológicos y de Vectores (CEPAVE) CONICET-CCT La Plata, Calle 120 S/N e/61 y 62, La Plata 1900, Buenos Aires, Argentina

${ }^{\mathrm{c}}$ Centre d'Ecologie Fonctionnelle et d'Evolution, UMR 5175, CNRS - Université de Montpellier - Université Paul Valéry Montpellier - EPHE, 1919 route de Mende, 34293 Montpellier Cedex 5, France

${ }^{\mathrm{d}}$ Carrera de Medicina, Facultad de Ciencias Médicas, Universidad Central del Ecuador, Quito, Ecuador

${ }^{\mathrm{e}}$ Research Unit in Parasitology and Parasitic Diseases, Fundamental and Applied Research for Animals and Health (FARAH), Faculty of Veterinary Medicine, University of Liège, Belgium

${ }^{\mathrm{f}}$ CIZ, Universidad Central de Ecuador, Quito, Ecuador

${ }^{\mathrm{g}}$ Center for Evolutionary and Theoretical Immunology, Museum of Southwestern Biology, Department of Biology, University of New Mexico, Albuquerque, NM87131, USA

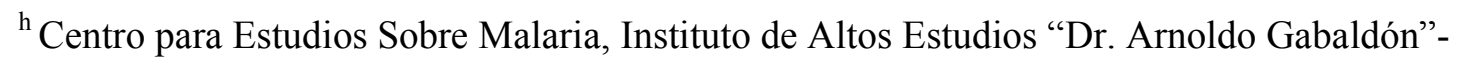
Instituto Nacional de Higiene "Rafael Rangel" del Ministerio del Poder Popular para la Salud y 
26 Sección de Biohelmintiasis, Instituto de Medicina Tropical, Facultad de Medicina, Universidad

27 Central de Venezuela. Caracas, Venezuela

$28{ }^{\text {i }}$ Facultad de Medicina Veterinaria y Zootecnia, Universidad Central del Ecuador, Quito,

29 Ecuador

$30 \quad{ }^{\text {j}}$ Escuela de Bacteriología y Laboratorio Clínico, Facultad de Salud, Universidad Industrial de

$31 \quad$ Santander, Bucaramanga, Colombia

${ }^{\mathrm{k}}$ USR 3278 CNRS-EPHE, CRIOBE Université de Perpignan, 68860 Perpignan-Cedex, France

${ }^{1}$ Département de Biologie-Ecologie, Faculté des Sciences, Université Montpellier, 34095

34 Montpellier Cedex 5, France

35 Corresponding author

36 Name: Manon Lounnas

37 Address: 900 rue Jean-François Breton

$38 \quad 34394$ Montpellier

$39 \quad$ France

40 Telephone/fax number: 0786853259

41 E-mail address: manon.lounnas@gmail.com 
42 Population structure and genetic diversity in the invasive freshwater snail

\section{3 Galba schirazensis (Lymnaeidae)}

M. Lounnas, A.C. Correa, P. Alda, M. Calvopiña, Y. Caron, M. Celi-Erazo, P. David, M.-P.

Dubois, B.T. Dung, P. Jarne, E.S. Loker, O. Noya, R. Rodríguez-Hidalgo, C. Toty, N. Uribe, J.P. Pointier, S. Hurtrez-Boussès

\section{Abstract}

We studied the population genetic structure of the freshwater snail Galba schirazensis (Küster, 1862), a potential vector of infectious diseases such as fascioliasis. Galba schirazensis has now a worldwide distribution but a poorly known origin because this species has been distinguished only recently from the morphologically similar and cosmopolitan Galba truncatula. We developed specific microsatellite markers and sequenced a mitochondrial gene (cytochrome oxidase subunit I) to study individuals of G. schirazensis from the Old World and New World. We found very low genetic diversity within populations, no heterozygotes, and marked population structure - a pattern observed in other highly selfing lymnaeid species with recently enlarged distributions as a result of biological invasions. The total lack of observed heterozygosity in the few populations of $G$. schirazensis that displayed some allelic diversity suggests high selfing rates. We also found that the center of diversity, and by extension the origin area of this species, should be found in the New World, while Old World populations should rather result from a recent introduction of a genetically uniform population. The microsatellite markers developed here will help to clarify the history of expansion of $G$. schirazensis and might help understanding its role as a potential vector of infectious diseases.

Keywords: lymnaeids; Lymnaea; Galba schirazensis; Galba truncatula; vector; microsatellites; selfing. 


\section{1. Introduction}

68 During the last century, human activities and climatic change have considerably accelerated the 69 spread of species across their natural barriers and modified their areas of distribution (Kolar and

Lodge 2001), threatening local biodiversity (Davis 2009). To better understand these threats, it is important to more fully characterize the species involved and the expansion pathways. Freshwater systems are particularly sensitive to bioinvasion risks (Beisel and Lévêque 2010). The Mollusca includes a large number of species invasive in freshwater habitats (Nunes et al. 2015). We here focus on the family Lymnaeidae in which several species have shown widespread long-distance colonization (Jabbour-Zahab et al. 1997; Meunier et al. 2001; Kopp et al. 2012; Lounnas et al. 2017). Long-distance dispersal can occur as a result of human activities, such as aquarium trade (Duggan 2010). Lymnaeids display marked resistance to desiccation which increases their survival probability (Chapuis and Ferdy 2012). If released in conducive new environments, even a single individual can found a population because lymnaeids are capable of self-fertilization, which also happens to be the main reproductive mode in some species (e.g., Meunier et al. 2004b; Escobar et al. 2011; Lounnas et al. 2016). Such colonization events may also spread food- and water-borne trematodes carried by lymnaeids (Meunier et al. 2001; Mas-Coma et al. 2005; Correa et al. 2010), either because dispersing snails are themselves infected or because their presence in a new location facilitates subsequent transmission that originates from nearby infected vertebrates. Importantly, the worldwide expansion of the liver fluke Fasciola hepatica, a parasite infecting livestock and humans, has been facilitated by the dispersal of lymnaeids (Hurtrez-Boussès et al. 2001; Mas-Coma et al. 2005).

9 Despite their relevance to human and animal health, lymnaeids have often been misidentified especially the Galba species, a phylogenetically distinct group of small-shelled lymnaeids (Correa et al. 2010; 2011; Lounnas et al. 2016). These species,, exhibit high phenotypic 
92 plasticity in shell shape and display extremely similar anatomical traits that make accurate

93 species identification difficult in the absence of molecular data (Samadi et al. 2000; Correa et al.

94 2011). For instance, Galba schirazensis (Küster, 1862) first described by Bargues et al (2011), has only recently been distinguished from Galba truncatula in Europe and Asia and from $G$. truncatula, Galba cubensis, and Galba viator in the Americas (Correa et al. 2010; 2011; Bargues et al. 2011). However, G. schirazensis is now described in many regions of the world, probably favored by its wide habitat range and its capacity to survive outside water for extended time periods (Bargues et al. 2011). Recent molecular-based studies reported G. schirazensis in Iran, Egypt, Reunion Island, Spain, Dominican Republic, Mexico, Colombia, Venezuela, Ecuador, and Peru (Bargues et al. 2011; Correa et al. 2010; 2011; reported as Lymnaea sp. and Galba sp. by the latter authors), but went of course unnoticed because the species was recently described. However, only highly conserved genetic markers have been used so far in species discrimination (Bargues et al. 2011; Correa et al. 2010, 2011). The population structure and genetic diversity of the invasive lymnaeid G. schirazensis remains therefore largely unknown.

We developed microsatellite markers in G. schirazensis and use them to genotype 242 individuals from 18 localities in Peru, Ecuador, Colombia, Venezuela, USA, Spain, and Reunion Island. We characterized the population structure and genetic diversity, and discuss our result in light of the breeding system and recent history of expansion of this species. We also assessed the specificity of these markers by testing amplification in the morphologically similar and closely related Galba species, i.e. G. truncatula, G. cubensis, and G. viator. We also sequenced a mitochondrial gene (cytochrome oxidase subunit I; CO1) to further elucidate the phylogeographic relationships among these populations and the populations studied by Bargues et al. (2011) and Correa et al. (2011). 
117

118

119

120

121

122

123

124

125

126

127

128

129

130

131

132

133

134

135

136

137

138

139

140

141

\section{Materials and methods}

\section{Development of specific microsatellite markers}

Snail DNA was extracted from four pooled individuals identified by Correa et al. (2011) as

Galba sp to reach a total of $2-3 \mu \mathrm{g}$ of total DNA. These individuals were collected in Río Negro, Antioquia, Colombia (N 0607’21” W 75²6’57’). DNA was extracted from foot tissue using the DNeasy Blood and Tissue Kit (Qiagen) and individuals were identified to species using the nuclear genes 18S (GenBank accession numbers: JN614335, JN614339, JN614340, JN614342), ITS-1 (HQ283253, JN614429, JN614430, JN614432), ITS-2 (HQ283263, JN614455, JN614456, JN614458), and the mtDNA gene CO1 (JN614370, JN614371, JN614373, JN614374). All these sequences showed $99-100 \%$ similarity with the sequences of G. schirazensis reported by Bargues et al. (2011).

Microsatellite loci were isolated from two enriched libraries (TC10 and TG10) following protocols described in Dubois et al. (2005) and using biotin-labeled microsatellite oligoprobes and streptavidin-coated magnetic beads. The enriched molecules were cloned into the pGEMt vector used to transform XL1-Blue Supercompetent Cells. Recombinant clones were screened with TC10, TG10, and AGE1 (AAACAGCTATGACCATGATTAC) or AGE2

(TTGTAAAACGACGGCCAGTG) oligonucleotides using a modified PCR method (Waldbieser 1995). We screened 228 clones, 163 of which gave a positive signal and were sequenced using an ABI Prism 3100 sequencer (Applied Biosystems). Ninety seven sequences included a repeated motif and flanking regions allowing determination of PCR primers that were designed using Primer3 (Rozen and Skaletsky 2000). We retained the 25 loci that showed the largest uninterrupted stretches of repeated motifs and selected the 22 ones that amplified successfully (Table 1). We tested these 22 microsatellite loci in six individuals from five localities from the Americas: Finca Jocum Bucaramanga (Colombia), Huagrahuma (Ecuador), Manto de la Novia (Ecuador), Louisiana Bedico (USA; 2 individuals), and Bodoque (Venezuela; Table 2, Fig. 1). 
142 We finally selected the 13 loci that were polymorphic in these six individuals for further

143 population genetic analyses.

144

145 To test the specificity of microsatellite markers, we also amplified these loci in individuals of 146 three species closely related to G. schirazensis: G. truncatula, G. cubensis, and G. viator. We 147 used two individuals of each species that were identified using the molecular markers 18S, ITS148 1, ITS-2, and CO1 (GenBank accession numbers in Correa et al. 2011).

\section{Population genetic analyses using microsatellite markers}

150

151

152

153

154

155

156

157

158

159

160

161

162

163

164

We analyzed 238 individuals of G. schirazensis from 16 localities from Colombia, Ecuador, Peru, USA, and Venezuela, as well as individuals from the Old World, one from Spain and three from Reunion Island (Table 2, Fig. 1). The Spanish specimen was collected from within the geographic range of G. truncatula and the population from Reunion Island was first ascribed to the introduced species G. truncatula (Griffiths and Florens 2006). The Spanish specimen was identified by Correa et al. (2011) as G. schirazensis using 18S, ITS-1, ITS-2 and COI (reported as Galba sp by the authors, GenBank accession numbers : JN614341, JN614436, JN614454, JN614377). We clearly identified the three individuals from La Reunion as G. schirazensis by analyzing the CO1 gene (GenBank accession numbers in Table 2) which presented $99-100 \%$ of similarity with the four sequences of G. schirazensis reported by Bargues et al. (2011) and only $90 \%$ with the sequence of $G$. truncatula from Spain reported by the same authors (AM494011) see also this study showing that all the highly specific microsatellite of G. schirazensis successfully amplified in these four individuals-. Despite the small sample sizes, we included these individuals in our analyses because they constitute the first mention of G. schirazensis in these two areas. All samples were collected from small areas $\left(<2 \mathrm{~m}^{2}\right)$ to prevent a Wahlund 
165 effect (Meunier et al. 2004a). Snails were killed in $70{ }^{\circ} \mathrm{C}$ water and immediately stored in $70 \%$ 166 ethanol.

167 For each specimen, we removed the distal part of the foot, which was twice compressed between 168 paper towels to remove excess ethanol. DNA extractions were then performed using $200 \mu \mathrm{l}$ of 169 5\% Chelex ${ }^{\circledR}$ (Chelex Bio Rad diluted in a Tris-EDTA buffer) solution incorporating $5 \mu$ of proteinase K (Sigma) at a concentration of $20 \mathrm{mg} / \mathrm{ml}$. This suspension was heated at $56{ }^{\circ} \mathrm{C}$ for 6 hours followed by gentle vortexing and a further incubation at $95{ }^{\circ} \mathrm{C}$ for $10 \mathrm{~min}$. The mixture was gently vortexed and centrifuged at $10,000 \mathrm{~g}$ for $10 \mathrm{sec}$. The supernatant $(100 \mu \mathrm{l})$ was collected, diluted 1: 10 in deionized water, and stored at $-20{ }^{\circ} \mathrm{C}$.

We amplified microsatellite loci in an Eppendorf Thermal Cycler, in a total volume of $10 \mu 1$ containing $5 \mu \mathrm{l}$ of Taq PCR Master Mix Kit (Qiagen), $1 \mu \mathrm{l}$ of the primer mix, the forward being labeled with a fluorochrome (see Table 1 for the labels of each locus), and $1 \mu$ of DNA. PCR conditions were as follow: 15 min activation at $95{ }^{\circ} \mathrm{C}, 35$ cycles including $30 \mathrm{sec}$ of initial denaturation at $94{ }^{\circ} \mathrm{C}, 90 \mathrm{sec}$ of annealing at $55^{\circ} \mathrm{C}$, and $60 \mathrm{sec}$ of extension at $72{ }^{\circ} \mathrm{C}$, followed by $30 \mathrm{~min}$ of final extension at $60^{\circ} \mathrm{C}$. . For genotyping, we pooled $3 \mu \mathrm{l}$ of diluted (1: 100) PCR products with $15 \mu 1$ of Hi-Di Formamide and $0.15 \mu$ of GeneScan-500 LIZ Size Standard and analyzed it on an ABI Prism 3100 Genetic Analyzer (Applied Biosystems). We performed multiplexed locus amplification by grouping loci as mentioned in Table 1. Multiplexing loci amplification was possible by using PCR products characterized by different sizes loci (no overlapping zones) and labelled with different fluorochromes. Allele sizes were read using GeneMapper ${ }^{\circledR}$ v.4.0 software (Applied Biosystems). Raw fragment sizes and corresponding peaks were manually checked one by one to discard error in this alleles calling step. Given the marked homozygosity, we evaluated our capacity to detect heterozygotes: we amplified loci combining DNA from two individuals exhibiting different genotypes. We both tested situations 
190 in which alleles exhibit a small size difference (one base pair) or a large one (40 base pair). In all 191 situations we were able detect heterozygotes.

192

193 We used the individual genotypes of the 238 American individuals to estimate allelic richness, 194 observed and expected heterozygosities, the $F$-statistic $F_{I S}$, and the selfing rate $(s)$ estimated as $s$ $195=2 F_{I S} /\left(1+F_{I S}\right)($ Hartl and Clark 1997). The global and pairwise differentiations among 196 populations were estimated using both $F_{S T}$ and $R_{S T}$. We could not use software that detect null 197 alleles because lymnaeids are hermaphroditic. Standard Bonferroni corrections were applied in 198 the case of multiple tests (Rice 1989). We analyzed data using Genodive (version 2.0b23; 199 Meirmans and Van Tienderen, 2004) and FSTAT (version 2.9.3.2; Goudet, 1995) software. 200 Individuals from Spain and Reunion Island were not included in the population genetic analysis 201 because the small sample sizes ( $N=1$ and $N=3$ respectibely) do not allow proper estimation of 202 population genetics parameters. However, we compared their genotypes to those of American 203 individuals. Multilocus genotypes were clustered using a discriminant analysis of principal 204 components (DAPC) using the adegenet package of R (Jombart et al. 2010). One of the main 205 advantages of this analysis is that it does not rely on a particular population genetic model and is 206 thus free of assumptions about Hardy-Weinberg or linkage equilibrium. Six principal 207 components were retained based on the $\alpha$-score. This score gives the number of principal 208 components optimized in order to capture the best discrimination without overfitting.

\section{Amplification, sequencing of $\mathrm{COI}$ and phylogeographic analysis}

We amplified and sequenced the CO1 gene in 21 snails from 11 populations (Fig. 3). Because of amplification failure due to DNA conservation issues, we did not sequence it in individuals from

213 Andaracas (Ecuador), Bodoque, Zea el Amparo, La Azulita, Bailadores, and San Eusebio

214 (Venezuela). The individual from El Rocío (Spain) was previously sequenced by Correa et al 
215 (2011) and we retrieved the sequence from Genbank (JN614377). The PCR primers were 216 LCO1490 (5'-GGTCAACAACTCATAAAGATATTGG-3') and HCO2198 (5'217 TAAACTTCAGGGTGACCAAAAAATCA-3') (Folmer et al. 1994). We used $2.5 \mu 1$ of DNA, 218 $12.5 \mu \mathrm{l}$ of Taq PCR Master Mix Kit (Qiagen), $2.5 \mu 1$ of each primer $(2 \mu \mathrm{M})$, and $5 \mu 1$ of distilled water. PCR conditions were as follow: $15 \mathrm{~min}$ activation at $95{ }^{\circ} \mathrm{C}, 35$ cycles including $30 \mathrm{sec}$ of

220 221 222 223 224 225 226 227 228 229 230 231 232 233 initial denaturation at $95^{\circ} \mathrm{C}, 1$ minute of annealing at $50{ }^{\circ} \mathrm{C}$, and $10 \mathrm{~min}$ of extension at $72{ }^{\circ} \mathrm{C}$, followed by 10 min of final extension at $72{ }^{\circ} \mathrm{C}$. Unidirectional DNA sequencing was performed by Eurofins MWG Operon (Germany) using the cycle sequencing technology (dideoxy chain termination / cycle sequencing) on ABI 3730XL sequencing machines (Applied Biosystems). Sequencing quality was assessed based on a quality score Q per base (values provided by Eurofins Genomics).

In addition, we downloaded from GenBank $12 \mathrm{CO} 1$ sequences of G. schirazensis from Iran, , Reunion Island, Peru, Ecuador, Colombia, Venezuela, and Mexico (JF272607-JF272610, Bargues et al. 2011; JN614370-JN614378, Correa et al. 2011), as well as one CO1 sequence of G. truncatula from France (JN614386, Correa et al. 2011), of G. viator from Argentina (JN872451, Standley et al. 2013) and of G. cubensis from Uruguay (JN614396, Correa et al. 2011).

These sequences were used for phylogeographic reconstruction, first aligning sequences using webPRANK (Löytynoja and Goldman 2010). The alignment was manually inspected using the electrophoregram of each sequence viewed on 4Peaks (Griekspoor and Groothuis 2005) and the quality report to discard Single Nucleotide Polymorphisms (SNPs) for which we had sequencing incertitudes $(Q<20)$. Then, we performed tree reconstruction using both Maximum Likelihood (ML) and Bayesian Inference (BI). ML analyses were conducted using the best-fitting model of sequence evolution. Model selection was based on Bayesian information criterion (BIC) using jModelTest (Posada 2008). We ran 5000 
240 bootstrap replications to test node robustness. BI analyses were performed with

241 MrBayes v3.2 (Ronquist and Huelsenbeck 2003). The tree space was explored using

242 Markov Chain Monte Carlo (MCMC) analyses with random starting trees and four

243 simultaneous, sequentially-heated independent chains sampled every 500 trees during

244 five million generations. Suboptimal trees were discarded once the "burn-in" phase was

245 identified and a majority-rule consensus tree, with posterior probability support of

246 nodes, was constructed with the remaining trees. The tree was visualized using FigTree

247 v1.4.2 (http://tree.bio.ed.ac.uk/software/figtree/). Both trees were edited with Adobe

248 Illustrator.

249 The number of haplotypes, the number of polymorphic sites, and the nucleotide diversity were

250 calculated using DnaSp V5 (Librado and Rozas 2009). Genetic distances were estimated

251 based on the number of base-pair differences per site (p-distance) among haplotypes

252 using Mega7 (Kumar et al. 2016). A minimum-spanning network was constructed using the

253 software SplitsTree4 (Huson and Bryant 2006) to represent the distances between haplotypes

254

255

\section{3. Results}

257

258

259

260

261

262

263

264
Approximate position of Table 1. 
265 We characterized the variation at the 13 polymorphic loci in all American individuals. The 266 number of alleles per locus was $2.846 \pm 0.274 \mathrm{SD}$, the observed heterozygosity was 0 at all loci, 267 and the mean expected heterozygosity was $0.007 \pm 0.005$ SD (Table 2). At most loci and 268 populations, the lack of diversity prevented us from estimating $F_{I S}$ (Table 2). Among the four 269 loci and populations that showed allelic diversity at some loci (Table S1), the observed heterozygosity was always zero $\left(F_{I S}=1, s=1\right.$; Table 2$)$.

271

272

273

274

275

276

277

278

279

280

281

282

283

284

285

286

287

288

289

Approximate position of Table 2.

We found high genetic differentiation among populations (global $F_{S T}=0.979 ; P<0.001$; global $R_{S T}=0.979 ; P<0.001$ ). All population pairs coming from different countries (except for Venezuela and Colombia) showed significant $F_{S T}$ after Bonferroni adjustment $(P=0.0004$;

Table S2). In contrast, populations from the same country or from adjacent countries usually showed no significant differentiation (Ecuador: $F_{S T}<0.019$, NS; Venezuela and Colombia: $F_{S T}<$ $0.235, \mathrm{NS})$. An exception is the Venezuelan population from La Trampa that differs significantly from most other Venezuelan and Colombian populations with $F_{S T}$ between 0.3 and 0.45 (Table S2).

Nine multilocus genotypes were found (Fig. 1). Some loci (1-8) could not be genotyped in some individuals $(N=65)$. Thus, we did not ascribe these individuals with incomplete genotypes to any multilocus genotype. However, the loci that could be genotyped in these individuals were exactly the same as in the individuals were all the loci were genotyped (Table S1). To analyze the genetic structure of populations using DAPC, we used all the individuals except for 12 individual genotypes that had more than three loci that did not amplify (Table S1). Four clusters were detected by DAPC which grouped together individuals from (1) Colombia, Venezuela, 
290 Spain, and Reunion Island, (2) Peru, (3) USA, and (4) Ecuador (Fig. 2; Table S1). Each cluster

291 consisted of a single main multilocus genotype with small within-cluster variation (Table S1).

292 Differences between the main genotypes and variants did not exceed one repeat (two base pairs),

293 and was of one base pair in some cases. The exception is Spanish genotype that differed from the

294 main type at two loci (Table S1). The main genotype from each cluster differed from those of

295 other clusters at five loci or more (Table S1). The largest difference was observed between

296 clusters from Ecuador and USA (all 13 loci fixed for different alleles).

297

298

299

300

301

302

303

304

305

306

307

308

309

310

311

312

313
Approximate position of Figure 1 .

Approximate position of Figure 2.

\section{COI sequences}

We obtained $21 \mathrm{CO} 1$ sequences of $G$. schirazensis (Table 2). The analysis of these sequences and sequences of G. schirazensis retrieved from GenBank revealed five haplotypes (number of sequences: 37 , nucleotide diversity: $0.005 \pm 0.001 \mathrm{SD}$ and haplotype diversity: $0.499 \pm 0.083$

SD) determined by 10 polymorphic sites without indels (Table S3). The CO1 sequences diverged from $0.2 \%$ (USA and Mexico; USA and Ecuador) to 1.6\% (USA and Peru - from Bargues et al. 2011) (Table S4).

The best model describing the evolution of the CO1 sequences was HKY+I. The Maximum Likelihood tree showed that these sequences pooled in three clades: (i) Ecuador (cluster 4 in DAPC), (ii) the single sequence from USA (cluster 3) and (iii) a worldwide clade including Peru (cluster 2), Venezuela, Colombia, Reunion Island and Spain (cluster 1). Genbank sequences from Iran, Venezuela, Colombia, and Reunion Island fell in the worldwide clade, those from Ecuador in the Ecuador clade and those from Mexico close to the USA sequence (Fig. 3). The Bayesian tree resulted in the same grouping (Fig. S1). However, the USA sequence grouped with the Ecuador clade in the ML tree while it grouped with the worldwide clade in the Bayesian tree. 
314 In both trees these nodes were not well supported by posterior probabilities and maximum

315 likelihood bootstrap (52-72\%).

316

The topologies of the Maximum Likelihood tree and the Bayesian trees were consistent with the results from DAPC, grouping those individuals from the same cluster in the same clade (Figs. 2,3 and S1). These analysis showed congruence between nuclear and mitochondrial genetic structure. Each mitochondrial haplotype included one to five multilocus microsatellite genotypes, and no multilocus microsatellite genotype was found associated with different mitochondrial haplotypes. However, the distance between DAPC clusters was in some cases lower than the phylogenetic distances. For instance, clusters 1 (worldwide) and 2 (Peru) were genetically distant from each other in the DAPC but they gathered in the same worldwide clade (Figs. 2 and 3). Also, the clusters 3 (USA) and 4 (Ecuador) were genetically distant from each other in the DAPC (Fig. 2) but they were genetically closed in the tree and the CO1 sequences diverged a little from each other ( $0.2 \%$, Table S3 and S4; Fig. 3 and 4$)$. In the minimumspanning network, North American haplotypes (3 and 4) appeared to be intermediates between worldwide and Ecuadorian haplotypes (1 and 5, Fig. 4). This inconsistency probably reflects the the fact that microsatellite loci are evolving much faster than mtDNA sequences.

Approximate position of Figure 3. Approximate position of Figure 4.

\section{Discussion}

We developed 13 polymorphic genetic markers to study the population structure and genetic diversity of G. schirazensis, an invasive freshwater snail inhabiting Asia, Europe, and the New World. These microsatellite loci appear to be specific to G. schirazensis because we did not find 
339

340

341

342

343

344

345

346

347

348

349

350

351

352

353

354

355

356

357

358

359

360

361

362

363

any amplification in the morphologically similar and most closely related species $G$. truncatula,

G. cubensis, and G. viator.

Analyzing New World populations, we observed very low genetic diversity within

populations, a total lack of heterozygotes, and marked population structure. The lack of observed heterozygosity in those few populations that showed allelic diversity suggests that $G$.

schirazensis mainly reproduces by self-fertilization. This is consistent with the fact that under laboratory conditions, individuals isolated from birth are able to self fertilize (Bargues et al.

2011). Our population genetic evidence for self-fertilization in natural population only relies on five locus-by-population combinations, all involving relatively rare alleles segregated in the populations (Tables 2, S1). In the absence of self-fertilization, rare alleles are expected to be mainly in the heterozygous state, so it would be very improbable for them to appear only as homozygotes in these five cases. Therefore, a high selfing rate is the most likely explanation for the lack of heterozygosity. In addition, related lymnaeid species exhibiting selfing rates in the 80-100\% range, for example G. cubensis (Lounnas et al. 2016), G. truncatula (Trouvé et al. 2000; Meunier et al. 2001; 2004a), Omphiscola glabra (Hurtrez-Boussès et al. 2005), and Pseudosuccinea columella (Nicot et al. 2008) which also show very low or no within-population allelic diversity, high $F_{I S}$, and large $F_{S T}$. In contrast, most populations of mainly outcrossing lymnaeids such as Lymnaea stagnalis (Puurtinen et al. 2007, Kopp et al. 2012, Besnard et al. 2013) and Radix sp. (Pfenninger et al. 2011) have high polymorphism, low $F_{I S}$, and moderate $F_{S T}$. Therefore, G. schirazensis shares the common characteristics of highly selfing lymnaeid species studied so far. It also shares a similar ecology with G. cubensis, G. truncatula, and $O$. glabra. All of them live mainly in temporary habitats that undergo frequent flooding and droughts that create strong bottlenecks (Meunier et al. 2004b). In this context, self-fertilization allows a single individual to colonize vacant habitats and to produce a new population (Meunier et al. 2004a). Finally, the recently analyzed transcriptomes of both $G$. truncatula and $G$. 
364 schirazensis bear molecular signatures consistent with ancient self-fertilization, dating back to 365 their common ancestor (Burgarella et al. 2015).

367 It is very difficult to know a priori where G. schirazensis was present before 2010, hence 368 whether each particular population is native or invasive. Galba schirazensis has probably been 369 misidentified in previous reports of small lymnaeid species from all over the world, either as $G$. 370 truncatula (everywhere) or as G. cubensis and G. viator (New World; Correa et al. 2010; 2011; Bargues et al. 2011) as they all have very similar shell morphology and internal anatomy. Thus, 373 it is impossible to trace invasion routes using reports from the literature, except for places known from historical records to be devoid of native small-shelled lymnaeids, such as Reunion Island 374 where the G. schirazensis populations necessarily result from introduction(s). The geographic 375 origin of G. schirazensis remains unknown. Bargues et al. (2011) assumed that this species is native to the Middle East as it was first described in Iran (Küster 1862). From this postulate the authors hypothesize two spreading waves, first an Old World spread (from Iran into Africa, Europe and Asia) and second a Trans-Atlantic spread into the Americas through the livestock transported by the Spanish conquerors during the early colonization period. However, as is typical of species descriptions of that time, only a brief description of the shell of G. schirazensis was provided, which could in practice fit with that of many small-shelled lymnaeids, including the very widespread G. truncatula. Therefore, the snail lineage studied in the present paper, redescribed on the basis of molecular sequences as G. schirazensis by Bargues et al. (2011), as

385 necessarily be (i) the same snail as that named G. schirazensis by Küster (1862) and (ii) native 386 from the Middle East. It current occurrence in Iran (Bargues et al. 2011) could well result from 387 an introduction. 
389 In this confused taxonomical situation, it is important to clearly list the available evidence on the

390 possible geographical origin of G. schirazensis. Any mention of this species can only be

391

392

393

ascertained based on molecular evidence in order to avoid misidentification. This eliminates all mentions prior to 2010, including the first description by Küster (1862). As a consequence, we must rely only on genetic diversity and phylogeny to identify likely origin areas. Bargues et al. (2011; Table 1) showed that all the individuals they sampled in the Old World (Iran, Egypt, and Spain) have exactly the same haplotypes at the nuclear genes18S, ITS-2, ITS-1 and the mitochondrial genes $16 \mathrm{~S}$ and $\mathrm{CO} 1$. However, they observed two to four different haplotypes for each gene in American populations (Dominican Republic, Mexico, Peru, Ecuador, and Venezuela), including the Old World haplotype. Our microsatellite study corroborates this pattern, as each of the four different regions sampled in the New World forms well-defined and differentiated clusters and the few individuals from two very distant places in the Old World (Reunion Island and Spain), including one from a known recent introduction (Reunion Island), are genetically related to only one of these clusters (Fig. 1). The phylogeographic tree is consistent with this pattern, since American $\mathrm{CO} 1$ sequences are variable while the sequences from the Old World showed no variation and belong all to the large worldwide clade (Fig. 3 and S2). All this suggests that the center of diversity, and by extension the origin area of this species, should be found in the New World, while Old World populations should rather result from a recent introduction of a genetically uniform population. In other snail species with the ability to self-fertilize, genetic uniformity over large distances and many populations is indeed the signature of recent introductions, for example in Lymnaea stagnalis introduced in New Zealand (Kopp et al. 2012), G. truncatula introduced on the Bolivian Altiplano (Meunier et al. 2001) or P. columella introduced in many parts of the world (Lounnas et al. 2017) . Finally, an American origin for G. schirazensis is also corroborated by the phylogeny of Correa et al. (2010), who concluded that the whole Galba clade likely has an American origin, as most of its species are 
native there (G. cousini, G. viator, G. neotropica, G. cubensis, G. humilis). The hypothesis of a post-Columbian introduction of G. schirazensis from Europe to the New World (Bargues et al. 2011), is not consistent with our findings: it would have been very unlikely to accumulate fixed differences at 13 distinct loci (as we observed between USA and Ecuador) in such a short time, while at the same time Venezuelan, Colombian, and Old World populations would remain nearly identical and devoid of diversity over huge geographical distances.

Although our data together along with the report of Bargues et al. (2011) seem sufficient to reject the hypothesis of a single recent introduction of G. schirazensis in the New World, more extensive sampling is needed (i) to test whether all the populations from the Old World have a single recent introduced origin, an hypothesis so far consistent with the results of conservative (Bargues et al. 2011, Correa et al. 2011, this study) and polymorphic (this study) markers and (ii) to more fully understand the genetic variation observed among South and North America isolates. The application of the genetic markers developed here to a more extensive sample that covers a worldwide range will therefore help to clarify the geographic origin and invasion routes of G. schirazensis.

Combining markers with contrasted mutation rates we observed discordances in genetic structuration between phylogenetic and DAPC analyses. Populations from Peru and populations distributed worldwide appeared to be significantly differentiated at a microsatellite level while they grouped in the same clade at a mitochondrial level (haplotype 1). Microsatellite loci have high mutation rates (between $10^{-2}$ and $10^{-4}$ per generation; Jarne and Lagoda 1996; Ellegren 2002) and tens of generations can generate mutations at least at one locus while several thousands of years are needed to generate one base substitution at the CO1 gene (around 1.35. $10^{-8} /$ site/year according Wilke et al. 2009). This result suggests that Peruvian population and 
439 populations that belong to the worldwide genotype probably diverged recently. Similarly, we

440 found that populations from Ecuador and USA were strongly differentiated at the nuclear level

441 while they were genetically closed at the mitochondrial level ( $0.2 \%$ of divergence) suggesting a

442 recent divergence event. Moreover sequences from USA and Mexico branched differentially

443 between the Bayesian tree and the maximum likelihood tree with moderate posterior

444 probabilities and maximum likelihood bootstrap. North American haplotypes appeared to be

445 intermediate between haplotype 1 (worldwide) and haplotype 5 (Ecuador) that were strongly

446 differentiated at both mitochondrial and microsatellite markers (1.2 \%, Fig. 4). Finally, we

447 cannot exclude the possibility of mtDNA introgression often responsible of mito-nuclear

448 discordance (Toewls and Brelsford 2012). This lack of clear structuration of North and South

449 American populations at a mitochondrial level shows that our sample size is too limited, and

450 more genetic markers would have been required to understand the fine-scale population

451 structure and bridging gaps in our understanding of both ancient population splits and more

452 recent expansion events of G. schirazensis.

453

454

455

456

457

458

459

460

461

462

463

Understanding the population structure and the genetic diversity of G. schirazensis can also help elucidating its role in spreading infectious diseases. Caron (2015) reported high prevalences of F. hepatica in G. schirazensis sampled in Ecuador. However, Bargues et al. (2011) who experimentally infected snails from one Egyptian and one Spanish localities observed that the parasite did not complete its life cycle. Dreyfuss et al. (2014) in experimental infections on successive generations of Colombian G. schirazensis detected prevalences ranging from 0 to $15.3 \%$ but free cercaria were only observed in two of the 400 studied snails. It is worth mentioning that, in the two studies cited above, only allopatric combinations have been tested and no experiment has been conducted so far with sympatric parasites. It therefore seems to be wise to consider $G$. schirazensis as a putative, perhaps occasional, intermediate host of $F$. 
464 hepatica. However, our capacity to identify which parasites are transmitted by G. schirazensis 465 has hitherto been hindered by the morphological similarity among Galba species (Correa et al. 466 2011). We need to identify by molecular means morphologically cryptic Galba species and to 467 identify the role of G. schirazensis as an intermediate host of food- and water-borne trematodes 468 such as F. hepatica.

469

In conclusion, our analysis provides strong support to the ideas that this species is predominantly 471 self-fertilizing, and has an American origin with recent colonization of the Old World by a 472 genetically uniform strain related to populations from Venezuela and Colombia — a hypothesis 473 that awaits confirmation by more extensive sampling.

474

475

\section{Acknowledgements}

476

478

479

480

481

482

483

484 485

We are most grateful to Nicolás Bonel for useful comments on an earlier draft of the manuscript.

We would like to thank Rolando Ayaqui for providing us specimens from Peru. ML was supported by a doctoral fellowship from University of Montpellier and a post-doctoral grant from Labex CeMeb, AC by a doctoral fellowship from IRD, PA by the Foundation Méditerranée Infection and SHB by University of Montpellier. This study was financially supported by IRD, CNRS, and University of Montpellier.

\section{References}

Bargues, M.D., Artigas, P., Khoubbane, M., Flores, R., Glöer, P., Rojas-García, R., Ashrafi, K., Falkner, G., and Mas-Coma, S. 2011. Lymnaea schirazensis, an overlooked snail distorting fascioliasis data: Genotype, phenotype, ecology, worldwide spread, susceptibility, applicability. PLoS ONE, 6 6: e24567. doi:10.1371/journal.pone.0024567. 
Beisel, J.N., and Lévêque, C. 2010. Introductions d'espèces dans les milieux aquatiques: faut-il avoir peur des invasions biologiques? Éditions Quae, c/o INRA, Versailles.

Besnard, A.L., Bouétard, A., Azam, D., and Coutellec, M.-A. 2013. Isolation and characterization of three new multiplex sets of microsatellite markers in the hermaphroditic freshwater snail Lymnaea stagnalis (Mollusca, Gastropoda, Heterobranchia, Panpulmonata, Hygrophila) using 454-pyrosequencing technology. Mol. Ecol. Resour. 13: 158-159.

Burgarella, C., Gayral, P., Ballenghien, M., Bernard, A., David, P., Jarne, P., Correa, A., Hurtrez-Bousses, S., Escobar, J., Galtier, N., and Glemin, S. 2015. Molecular evolution of freshwater snails with contrasting mating systems. Mol. Biol. Evol. 32(9): 2403-2416. doi:10.1093/molbev/msv121.

Chapuis, E., and Ferdy, J.B. 2012. Life history traits variation in heterogeneous environment: The case of a freshwater snail resistance to pond drying. Ecol. Evol. 2(1): 218-226. doi:10.1002/ece3.68.

Correa, A., Escobar, J., Durand, P., Renaud, F., David, P., Jarne, P., Pointier, J.-P., and HurtrezBousses, S. 2010. Bridging gaps in the molecular phylogeny of the Lymnaeidae (Gastropoda: Pulmonata), vectors of Fascioliasis. BMC Evol. Biol. 10(1): 381. doi:10.1186/1471-2148-10-381.

Correa, A.C., Escobar, J.S., Noya, O., Velásquez, L.E., González-Ramírez, C., Hurtrez-Boussès, S., and Pointier, J.P. 2011. Morphological and molecular characterization of Neotropic Lymnaeidae (Gastropoda: Lymnaeoidea), vectors of fasciolosis. Infect. Genet. Evol. 11(8): 1978-1988. doi:10.1016/j.meegid.2011.09.003.

Davis, M.A. 2009. Invasion biology. Oxford University Press, Oxford. doi:10.2134/jeq2004.2384.

Dubois, M.P., Jarne, P., and Jouventin, P. 2005. Ten polymorphic microsatellite markers in the 
512

513

514

515

516

517

518

519

520

521

522

523

524

525

526

527

528

529

530

531

532

533

534

wandering albatross Diomedea exulans. Mol. Ecol. Notes 5(4): 905-907. doi:10.1111/j.1471-8286.2005.01108.x.

Duggan, I.C. 2010. The freshwater aquarium trade as a vector for incidental invertebrate fauna. Biol. Invasions 12(11): 3757-3770. doi:10.1007/s10530-010-9768-x.

Ellegren H. 2002. Microsatellite evolution: a battle between replication slippage and point mutation. Trends Genet. 18: 70.

Escobar, J.S., Auld, J.R., Correa, A.C., Alonso, J.M., Bony, Y.K., Coutellec, M.A., Koene, J.M., Pointier, J.P., Jarne, P., and David, P. 2011. Patterns of mating-system evolution in hermaphroditic animals: Correlations among selfing rate, inbreeding depression, and the timing of reproduction. Evolution (N. Y). 65(5): 1233-1253. doi:10.1111/j.15585646.2011.01218.x.

Folmer, O., Black, M., Hoeh, W., Lutz, R., and Vrijenhoek, R. 1994. DNA primers for amplification of mitochondrial cytochrome c oxidase subunit I from diverse metazoan invertebrates. Mol. Mar. Biol. Biotechnol. 3(5): 294-299. doi:10.1371/journal.pone.0013102.

Goudet, J. 1995. FSTAT (Version 1.2): A Computer Program to Calculate F-Statistics. J. Hered. 86: $485-486$.

Griekspoor, A., and Groothuis, T. 2005. 4Peaks: a program that helps molecular biologists to visualize and edit their DNA sequence files v1. 7. Available at: http://nucleobytes. com

Griffiths, O.L., and Florens, F.B.V. 2006. A field guide to the non-marine molluscs of the Mascarene Islands (Mauritius, Rodrigues and Réunion) and the Northern dependencies of Mauritius. Bioculture Press.

Hartl, D., and Clark, A. 1997. Principles of Population Genetics. Sinauer Associates Inc., U.S. 
535

536

537

538

539

540

541

542

543

544

545

546

547

548

549

550

551

552

553

554

555

556

557

Hurtrez-Boussès, S., Meunier, C., Durand, P., and Renaud, F. 2001. Dynamics of host - parasite interactions: the example of population biology of the liver fluke (Fasciola hepatica). Microbes Infect. 3: 841-849. doi:10.1016/S1286-4579(01)01442-3.

Hurtrez-Boussès, S., Pendino, A., Barnabé, C., Durand, P., Rondelaud, D., Durand, C., Meunier, C., Hurtrez, J., and Renaud, F. 2005. Comparison between shell morphology and genetic diversity in two sympatric lymnaeid snails, vectors of fasciolosis. Can. J. Zool. 83: $1643-$ 1648. doi:10.1139/Z05-150.

Huson D.H., Bryant D. 2006. Application of phylogenetic networks in evolutionary studies. Mol. Biol. Evol. 23: 254-267.

Jabbour-Zahab, R., Pointier, J.P., Jourdane, J., Jarne, P., Oviedo, J. a, Bargues, M.D., MasComa, S., Anglés, R., Perera, G., Balzan, C., Khallayoune, K., and Renaud, F. 1997. Phylogeography and genetic divergence of some lymnaeid snails, intermediate hosts of human and animal fascioliasis with special reference to lymnaeids from the Bolivian Altiplano. Acta Trop. 64(3-4): 191-203. Available from http://www.ncbi.nlm.nih.gov/pubmed/9107366.

Jarne P., Lagoda P.J. 1996. Microsatellites, from molecules to populations and back. Trends Ecol. Evol. 11: 424-429.

Jombart, T., Devillard, S., and Balloux, F. 2010. Discriminant analysis of principal components: a new method for the analysis of genetically structured populations. BMC Genet. 11(1): 94. doi:doi: 10.1186/1471-2156-11-94.

Kolar, C.S., and Lodge, D.M. 2001. Progress in invasion biology: Predicting invaders. Trends Ecol. Evol. 16(4): 199-204. doi:10.1016/S0169-5347(01)02101-2. 
$55^{8}$ Kopp, K.C., Wolff, K., and Jokela, J. 2012. Natural range expansion and human-assisted 559 introduction leave different genetic signatures in a hermaphroditic freshwater snail. Evol. 560 Ecol. 26(3): 483-498. doi:10.1007/s10682-011-9504-8.

561 Kumar, S., Stecher, G., and Tamura, K. 2016. MEGA7: Molecular Evolutionary Genetics 562 Analysis version 7.0 for bigger datasets. Mol. Biol. Evol. 33(7): msw054. 563 doi:10.1093/molbev/msw054.

564 Küster, H. 1862. Die Gattungen Limnaeus, Amphipeplea, Chilina, Isidora und Physopsis. In 565 Systematisches Conchylien-Cabinet, 2nd Editio. Edited by F.H.W. Martini and J.H. 566 Chemnitz. Bauer and Raspe, Nürnberg. p. I.17 b: issues 180-182:. 1-48, pls. 1-11 (1862); i.

567 Librado, P., and Rozas, J. 2009. DnaSP v5: A software for comprehensive analysis of DNA 568 polymorphism data. Bioinformatics 25(11): 1451-1452. doi:10.1093/bioinformatics/btp187.

569 Lounnas, M., Vázquez, A.A., Alda, P., Sartori, K., Pointier, J.-P., David, P., and Hurtrez570 Boussès, S. 2016. Isolation, characterization and population-genetic analysis of 571 572 microsatellite loci in the freshwater snail Galba cubensis (Lymnaeidae). J. Molluscan Stud.

573 574 575
Lounnas M., Correa A.C., Vázquez A.A. et al. (2017) Self-fertilization, long-distance flash invasion and biogeography shape the population structure of Pseudosuccinea columella at the worldwide scale. Mol. Ecol. 26(3): 887-903.

Mas-Coma, S., Bargues, M., and Valero, M. 2005. Fascioliasis and other plant-borne trematode zoonoses. Int. J. Parasitol. 35: 1255-1278.

Meirmans, P.G., and Van Tienderen, P.H. 2004. GENOTYPE and GENODIVE: Two programs for the analysis of genetic diversity of asexual organisms. Mol. Ecol. Notes 4(4): 792-794. doi:10.1111/j.1471-8286.2004.00770.x. 
581 Meunier, C., Hurtrez-Bousses, S., Durand, P., Rondelaud, D., and Renaud, F. 2004a. Small 582 effective population sizes in a widespread selfing species, Lymnaea truncatula (Gastropoda: 583 Pulmonata). Mol. Ecol. 13(9): 2535-2543. doi:10.1111/j.1365-294X.2004.02242.x.

584 Meunier, C., Hurtrez-Boussès, S., Jabbour-Zahab, R., Durand, P., Rondelaud, D., and Renaud, F. $5852004 b$. Field and experimental evidence of preferential selfing in the freshwater mollusc 586 Lymnaea truncatula (Gastropoda, Pulmonata). Heredity (Edinb). 92(4): 316-322. $587 \quad$ doi:10.1038/sj.hdy.6800410.

588 Meunier, C., Tirard, C., Hurtrez-Boussès, S., Durand, P., Bargues, M.D., Mas-Coma, S., 589 Pointier, P., Jourdane, J., and Renaud, F. 2001. Lack of molluscan host diversity and the 590 transmission of an emerging parasitic disease in Bolivia. Mol. Ecol. 10(5): 1333-1340. 591 doi:10.1046/j.1365-294X.2001.01284.x.

592 Nicot, A., Dubois, M.P., Debain, C., David, P., and Jarne, P. 2008. Characterization of 15 593 microsatellite loci in the pulmonate snail Pseudosuccinea columella (Mollusca, 594 Gastropoda). Mol. Ecol. Resour. 8(6): 1281-1284. doi:10.1111/j.1755-0998.2007.02065.x. 595 596 597 598 599 600 601 602 603 604

Nunes, A.L., Tricarico, E., Panov, V.E., Cardoso, A.C., and Katsanevakis, S. 2015. Pathways and gateways of freshwater invasions in Europe. Aquat. Invasions 10(4): 359-370. doi:10.3391/ai.2015.10.4.01.

Pfenninger, M., Salinger, M., Haun, T., and Feldmeyer, B. 2011. Factors and processes shaping the population structure and distribution of genetic variation across the species range of the freshwater snail Radix balthica (Pulmonata, Basommatophora). BMC Evol. Biol. 11(1): 135. doi:10.1186/1471-2148-11-135.

Posada, D. 2008. jModelTest: phylogenetic model averaging. Mol. Biol. Evol. 25(7): 1253-1256.

Puurtinen, M., Knott, K.E., Suonpää, S., Nissinen, K., and Kaitala, V. 2007. Predominance of outcrossing in Lymnaea stagnalis despite low apparent fitness costs of self-fertilization. J. 
605

606

607

608

609

610

611

612

613

614

615

616

617

618

619

620

621

622

623

624

625

626

627

628

Rice, R. 1989. Analyzing tables of statistical tests. Evolution (N. Y). 43(1): 223-224.

Ronquist, F. and Huelsenbeck, J. P. 2003. MrBayes 3: Bayesian phylogenetic inference under mixed models. Bioinformatics, 19(12): 1572-1574.

Rozen, S., and Skaletsky, H. 2000. Primer3 on the WWW for General Users and for Biologist Programmers. In Bioinformatics Methods and Protocols. Edited by S. Misener and S.A. Krawetz. Methods in Molecular Biology ${ }^{\mathrm{TM}}$, vol. 132. Humana Press, Totowa, NJ. pp. $365-$ 386.

Samadi, S., Roumegoux, A., Bargues, M.D., Mas-Coma, S., Yong, M., and Pointier, J.P. 2000. Morphological studies of Lymnaeid snails from the human fascioliasis endemic zone of Bolivia. J. Molluscan Stud. 66: 31-44. doi:10.1093/mollus/66.1.31.

Trouvé, S., Degen, L., Meunier, C., Tirard, C., Hurtrez-Boussès, S., Durand, P., Guegan, J., Goudet, J., and Renaud, F. 2000. Microsatellites in the hermaphroditic snail, Lymnaea truncatula, intermediate host of the liver fluke, Fasciola hepatica. Mol. Ecol. 9(10): 16621664. doi:10.1046/j.1365-294X.2000.01043-3.x.

Waldbieser, G. 1995. PCR-based identification of AT-rich tri- and tetranucleotide repeat loci in an enriched plasmid library. Biotechniques 19(5): 742-744.

Wilke, T., Schultheiß, R., Albrecht, C. 2009. As time goes by: A simple fool's guide to molecular clock approaches in invertebrates. Am. Malacol. Bull. 27: 25-45. 
629 Table 1. Microsatellite loci in Galba schirazensis. Description of loci and genetic variation in 630 six individuals from five localities (polymorphic loci in bold characters). Annealing 631 temperature is $55^{\circ} \mathrm{C}$ for all loci. Na, number of alleles detected; RAS, range of allele size 632 (in base pairs).

633

Locus Primer sequences $\left(5^{\prime} \rightarrow 3^{\prime}\right)$

\begin{tabular}{llllll}
$\begin{array}{l}\text { Label } \\
\text { dye }\end{array}$ & $\begin{array}{l}\text { Multiplex } \\
\text { set }\end{array}$ & $\begin{array}{l}\text { GenBank } \\
\text { accession } \\
\text { number }\end{array}$ & Repeat motif & Na & RAS \\
\hline & & & &
\end{tabular}

\begin{tabular}{|c|c|c|c|c|c|c|c|}
\hline Gsch_1 & F: TTTTGGGTCAACATTAGGTTAGG & PET & A & KT324711 & $(\mathrm{TC})_{13}$ & 3 & $213-249$ \\
\hline & R: GAACATTTGACACAGTAGCGTTG & & & & & & \\
\hline Gsch_2 & F: ACGTGCACACTTCTCCCTCT & PET & & KT324709 & $(\mathrm{CT})_{23}$ & 1 & 185 \\
\hline & R: GCCTTGGTGCAGTTTTGTATT & & & & & & \\
\hline Gsch_3 & F: TGTAGGCAAAGGCACAAAAA & PET & B & KT324702 & $(\mathrm{CT})_{13}$ & 4 & $152-178$ \\
\hline & R: AGGGTGTAAGGGCTGAATTG & & & & & & \\
\hline Gsch_4 & F: TTCATTGTCTGCTCCTGCTG & VIC & B & KT324708 & $(\mathrm{TC})_{20}(\mathrm{CT})_{13}$ & 2 & $157-160$ \\
\hline & R: CGCCACTGGTCGATAGACTT & & & & & & \\
\hline Gsch_5 & F: GGTCGTTTAGCAGCCTAGCA & NED & A & KT324710 & $(\mathrm{GT})_{10}(\mathrm{AG})_{13}$ & 2 & $179-185$ \\
\hline & R: CGACCGTTCAAACGTTACTG & & & & & & \\
\hline Gsch_7 & F: AAACGACCGTTTCTAAGGTGA & VIC & & KT324707 & $(\mathrm{AG})_{23}$ & 1 & 244 \\
\hline & R: CCCTGAACCAACAGAGCATT & & & & & & \\
\hline Gsch_9 & F: GGCGGAAACGAAGAGAGTAA & NED & B & KT324705 & $(\mathrm{TC})_{11}$ & 4 & $207-227$ \\
\hline & R: TACGTGCACACACTCAACCA & & & & & & \\
\hline Gsch_10 & F: AGGAGAGTCCCATTGAGCTG & PET & & KT324706 & $(\mathrm{GT})_{11}$ & 1 & 218 \\
\hline & R: CGAAACTGTTGAAGGCATTG & & & & & & \\
\hline Gsch_11 & F: AАCACATTTCCACCCACACA & FAM & B & KT324712 & $(\mathrm{CT})_{18}$ & 2 & $216-235$ \\
\hline & R: CTTTCTTTCGCGTGGGGTAT & & & & & & \\
\hline Gsch_12 & F: CTGGGGCTAACCCAAGAATC & FAM & & KT324713 & $(\mathrm{TG})_{10}$ & 1 & 151 \\
\hline & R: TTTGGGGTTGAGGGCTTTAT & & & & & & \\
\hline Gsch_13 & F: TCACGTTCTCGTGGTTCTCA & VIC & $\mathrm{C}$ & KT324714 & $(\mathrm{CA})_{10}$ & 5 & $166-173$ \\
\hline & R: GTCGATGGGGCTATGTGTCT & & & & & & \\
\hline Gsch_14 & F: CGATGGCGCCAACTTATTTA & VIC & A & KT324715 & $(\mathrm{CA})_{10}$ & 2 & $201-222$ \\
\hline & R: TCATATCGCTACGGACATTCA & & & & & & \\
\hline Gsch_15 & F: TGAGACGGGCAAGATTTCTC & NED & & KT324716 & $(\mathrm{CT})_{15}$ & 1 & 154 \\
\hline
\end{tabular}


R: AGGGTTCGATTCCCATCTCT

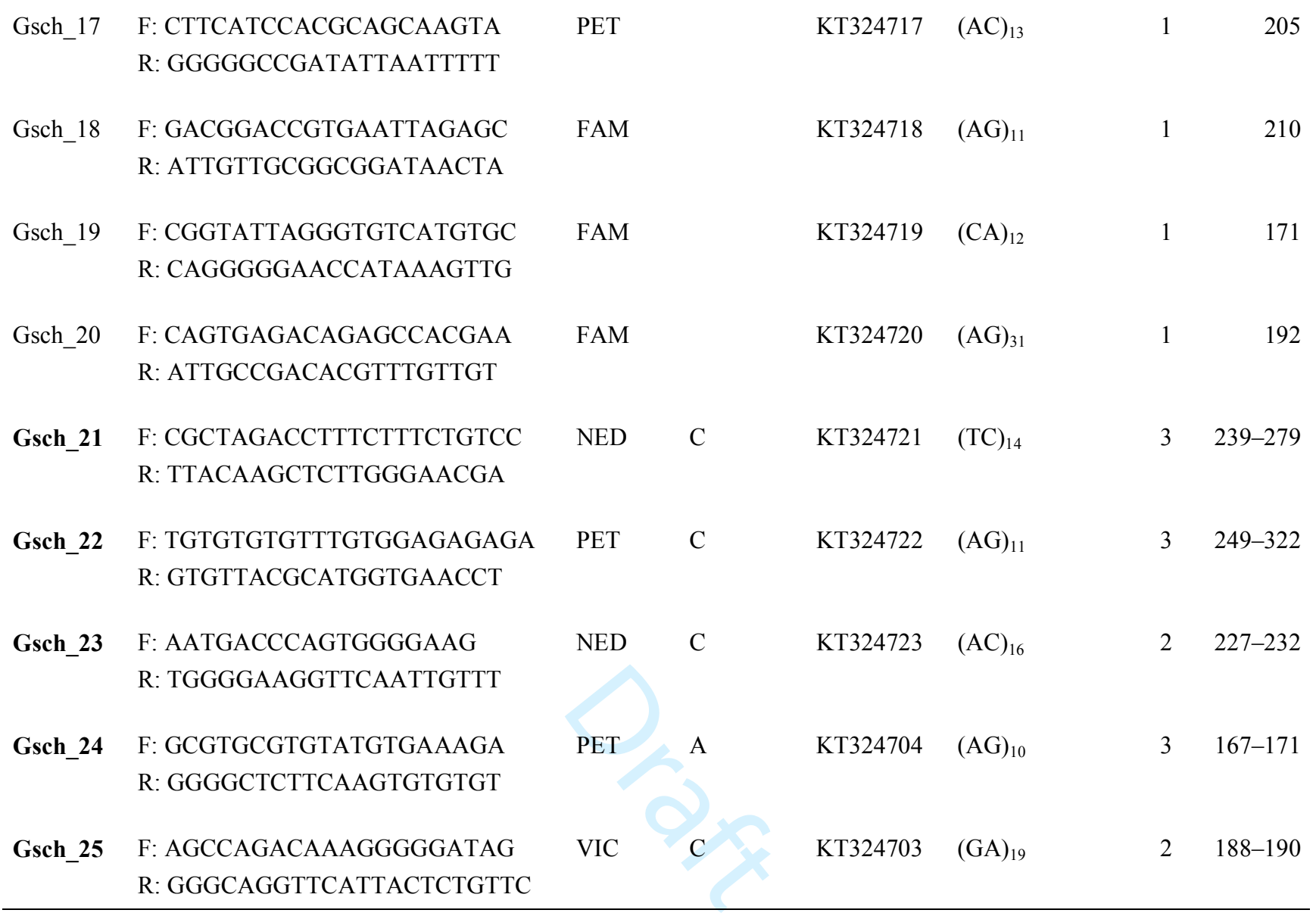


Table 2. Populations of Galba schirazensis and their genetic variability. Genetic parameters were not calculated in the samples from Spain and La Réunion Island because of too small sample size. $\mathrm{N}$, sample size; Na, mean number of alleles; He, expected heterozygosity; $F_{I S}$, inbreeding coefficient and $P$-value; NA, not available. Bonferroni corrections were applied $(P=0.0125)$. Observed heterozygosity was null in all populations.

\begin{tabular}{|c|c|c|c|c|c|c|c|c|c|c|}
\hline Country & Location & Acronym & Coordinates & $\begin{array}{l}\text { Sampling } \\
\text { year }\end{array}$ & GenBank accession number & $\mathrm{N}$ & $\mathrm{Na}$ & $\mathrm{He}$ & $F_{I S}$ & $\begin{array}{r}\text { Estimated } \\
\text { selfing rate }\end{array}$ \\
\hline Peru & La Joya de Arequipa & LJ & $16^{\circ} 28^{\prime} 56^{\prime \prime}$ S 71²4'07" W & 2012 & KY198250, KY198260 & 14 & 1.000 & 0.000 & - & - \\
\hline \multirow[t]{5}{*}{ Ecuador } & Huagrahuma & $\mathrm{HU}$ & $02^{\circ} 47^{\prime} 32^{\prime \prime} \mathrm{S} 79^{\circ} 16^{\prime} 31^{\prime \prime} \mathrm{W}$ & 2012 & KT781302, КT781304 & 13 & 1.000 & 0.000 & - & - \\
\hline & Manto de la Novia & $\mathrm{MN}$ & $01^{\circ} 24^{\prime} 03^{\prime \prime} \mathrm{S} 78^{\circ} 17^{\prime} 49^{\prime \prime} \mathrm{W}$ & 2011 & KT781305, KT781315 & 15 & 1.000 & 0.000 & - & - \\
\hline & Hacienda Cienaga & $\mathrm{HC}$ & $00^{\circ} 46^{\prime} 18^{\prime \prime} \mathrm{S} 78^{\circ} 37^{\prime} 10^{\prime \prime} \mathrm{W}$ & 2011 & KT781301 & 12 & 1.000 & 0.000 & - & - \\
\hline & Andaracas & $\mathrm{AN}$ & $00^{\circ} 26^{\prime} 10^{\prime \prime} \mathrm{S} 78^{\circ} 32^{\prime} 22^{\prime \prime} \mathrm{W}$ & 2014 & - & 14 & 1.077 & 0.013 & $\begin{array}{r}1 \\
(<0.0001)\end{array}$ & 1 \\
\hline & Nono & $\mathrm{NO}$ & $00^{\circ} 03^{\prime} 25^{\prime \prime} \mathrm{S} 78^{\circ} 34^{\prime} 15^{\prime \prime} \mathrm{W}$ & 2014 & KY198255, KY198256 & 16 & 1.000 & 0.000 & - & - \\
\hline Colombia & $\begin{array}{l}\text { Finca Jocum } \\
\text { Bucaramanga }\end{array}$ & FJ & $07^{\circ} 06^{\prime} 25^{\prime \prime} \mathrm{N} 73^{\circ} 04^{\prime} 60^{\prime \prime} \mathrm{W}$ & 2012 & KY198253, KY198254 & 14 & 1.000 & 0.000 & - & - \\
\hline \multirow[t]{7}{*}{ Venezuela } & Bodoque & $\mathrm{BO}$ & $08^{\circ} 16^{\prime} 15^{\prime \prime} \mathrm{N} 71^{\circ} 48^{\prime} 51^{\prime \prime} \mathrm{W}$ & 2005 & - & 18 & 1.077 & 0.033 & $\begin{array}{r}1 \\
(<0.0001)\end{array}$ & 1 \\
\hline & Los Nevados & $\mathrm{LN}$ & $08^{\circ} 27^{\prime} 41^{\prime \prime} \mathrm{N} 71^{\circ} 04^{\prime} 28^{\prime \prime} \mathrm{W}$ & 2013 & KT781320 & 18 & 1.000 & 0.000 & - & - \\
\hline & Zea el Amparo & $\mathrm{ZA}$ & $08^{\circ} 21^{\prime} 40^{\prime \prime} \mathrm{N} 71^{\circ} 46^{\prime} 01^{\prime \prime} \mathrm{W}$ & 2005 & - & 9 & 1.000 & 0.000 & - & - \\
\hline & La Azulita & LA & $08^{\circ} 44^{\prime} 06^{\prime \prime} \mathrm{N} 71^{\circ} 26^{\prime} 49^{\prime \prime} \mathrm{W}$ & 2005 & - & 11 & 1.000 & 0.000 & - & - \\
\hline & Bailadores & BA & $08^{\circ} 14^{\prime} 05^{\prime \prime} \mathrm{N} 71^{\circ} 50^{\prime} 26^{\prime \prime} \mathrm{W}$ & 2005 & - & 18 & 1.000 & 0.000 & - & - \\
\hline & San Eusebio & $\mathrm{SE}$ & $08^{\circ} 38^{\prime} 39^{\prime \prime} \mathrm{N} 71^{\circ} 23^{\prime} 42^{\prime \prime} \mathrm{W}$ & 2005 & - & 18 & 1.000 & 0.000 & - & - \\
\hline & Sabana Alto & SA & $08^{\circ} 36^{\prime} 11^{\prime \prime} \mathrm{N} 71^{\circ} 27^{\prime} 45^{\prime \prime} \mathrm{W}$ & 2013 & $\begin{array}{l}\text { KT781322, KT781323, } \\
\text { KT781324 }\end{array}$ & 7 & 1.000 & 0.000 & - & - \\
\hline
\end{tabular}




\begin{tabular}{|c|c|c|c|c|c|c|c|c|c|c|}
\hline & La Trampa & LT & $08^{\circ} 33^{\prime} 31^{\prime \prime} \mathrm{N} 71^{\circ} 27^{\prime} 13^{\prime \prime} \mathrm{W}$ & 2013 & KY198251, KY198252 & 20 & 1.154 & 0.048 & $\begin{array}{r}1 \\
(<0.0001)\end{array}$ & 1 \\
\hline USA & Louisiana Bedico & LB & $30^{\circ} 26^{\prime} 11^{\prime \prime} \mathrm{N} 90^{\circ} 15^{\prime} 01^{\prime \prime} \mathrm{W}$ & NA & KT781332 & 21 & 1.077 & 0.015 & $\begin{array}{r}1 \\
(<0.0001)\end{array}$ & 1 \\
\hline Spain & El Rocío & ER & $37^{\circ} 08^{\prime} 02^{\prime \prime} \mathrm{N} 06^{\circ} 28^{\prime} 18^{\prime \prime} \mathrm{W}$ & 2010 & JN614377 & 1 & - & - & - & - \\
\hline $\begin{array}{l}\text { La Reunion } \\
\text { Island (France) }\end{array}$ & Ravine du Gol & RG & $21^{\circ} 14^{\prime} 26^{\prime \prime} \mathrm{S} 55^{\circ} 25^{\prime} 07^{\prime \prime} \mathrm{E}$ & 2009 & $\begin{array}{l}\text { KY198257, KY198258, } \\
\text { KY198259 }\end{array}$ & 3 & - & - & - & - \\
\hline
\end{tabular}




\section{Figure legends}

Figure 1. Geographic location of multilocus microsatellite genotypes of Galba schirazensis. Each multilocus genotype is figured by a color and a letter. Each pie chart represents a population. See Table 2 for population acronyms.

Figure 2. Genetic population structure of Galba schirazensis. Scatter plot of 230 individuals on the first two DAPC axes (first axis: $61 \%$ of total variance; second axis: $22 \%$ ). Individuals group in four clusters.

Figure 3. Maximum-likelihood phylogenetic tree of Galba schirazensis based on mtDNA CO1 sequences. Bootstrap values are indicated at each node. Sequences are given their GenBank accession numbers. Colored sequences are those obtained in this study, the others having been retrieved from GenBank. Galba viator JN872451 sequence (Standley et al. 2013) was used as outgroup. For each sequence obtained here, the color code refers to the cluster number derived from DAPC.

Figure 4. Minimum-spanning network of COI haplotypes from Galba schirazensis. Colors and haplotypes are those refered in the table S4. Each circle represents a haplotype, its size being proportional to the frequency of occurrence of a certain haplotype. Numbers of haplotype occurrences are indicated in each circle. 


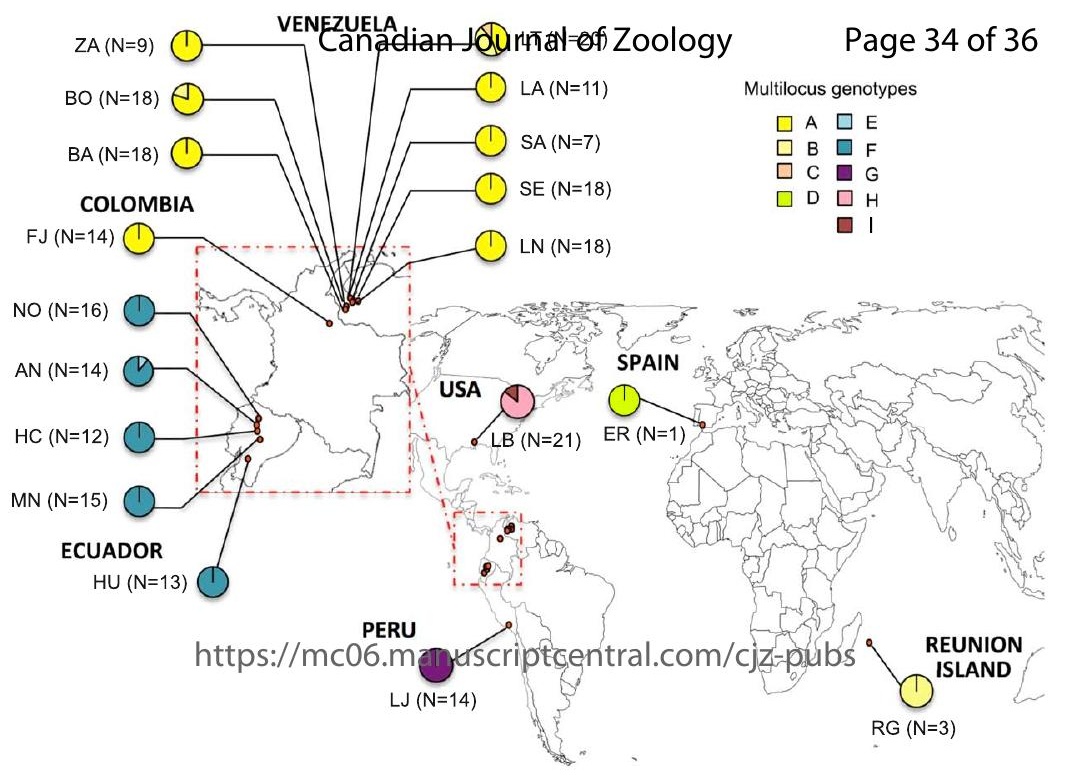


ECUADOR

\author{
COLOMBIA \\ VENEZUELA \\ SPAIN \\ REUNION ISLAND
}

$<4=?$

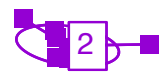

\title{
PERU
}

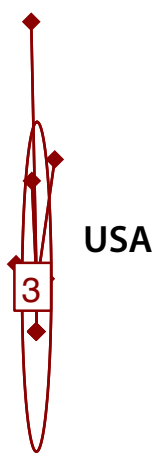

https://mc06.manuscriptcentral.conp/cjz-pubs 


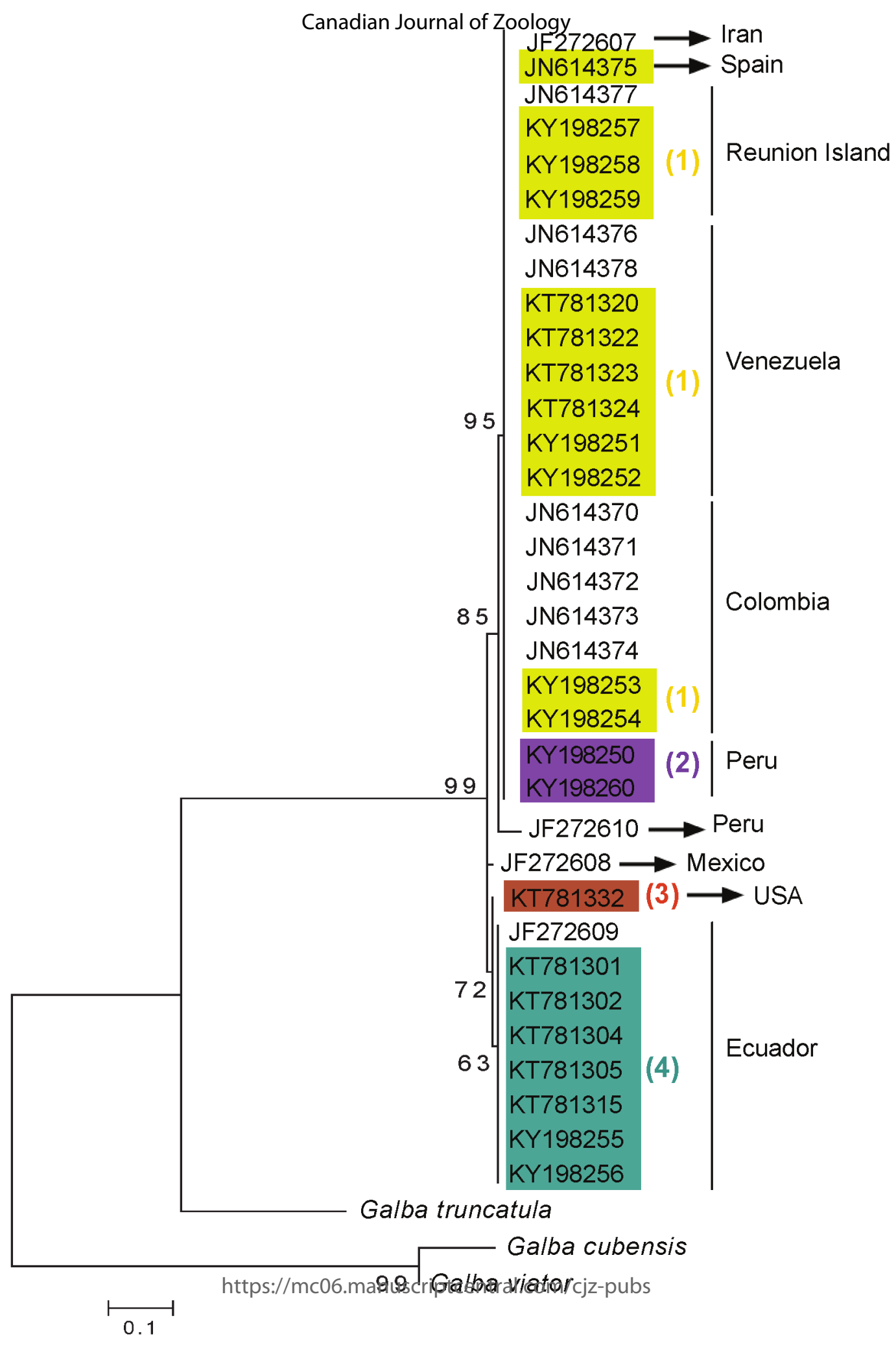




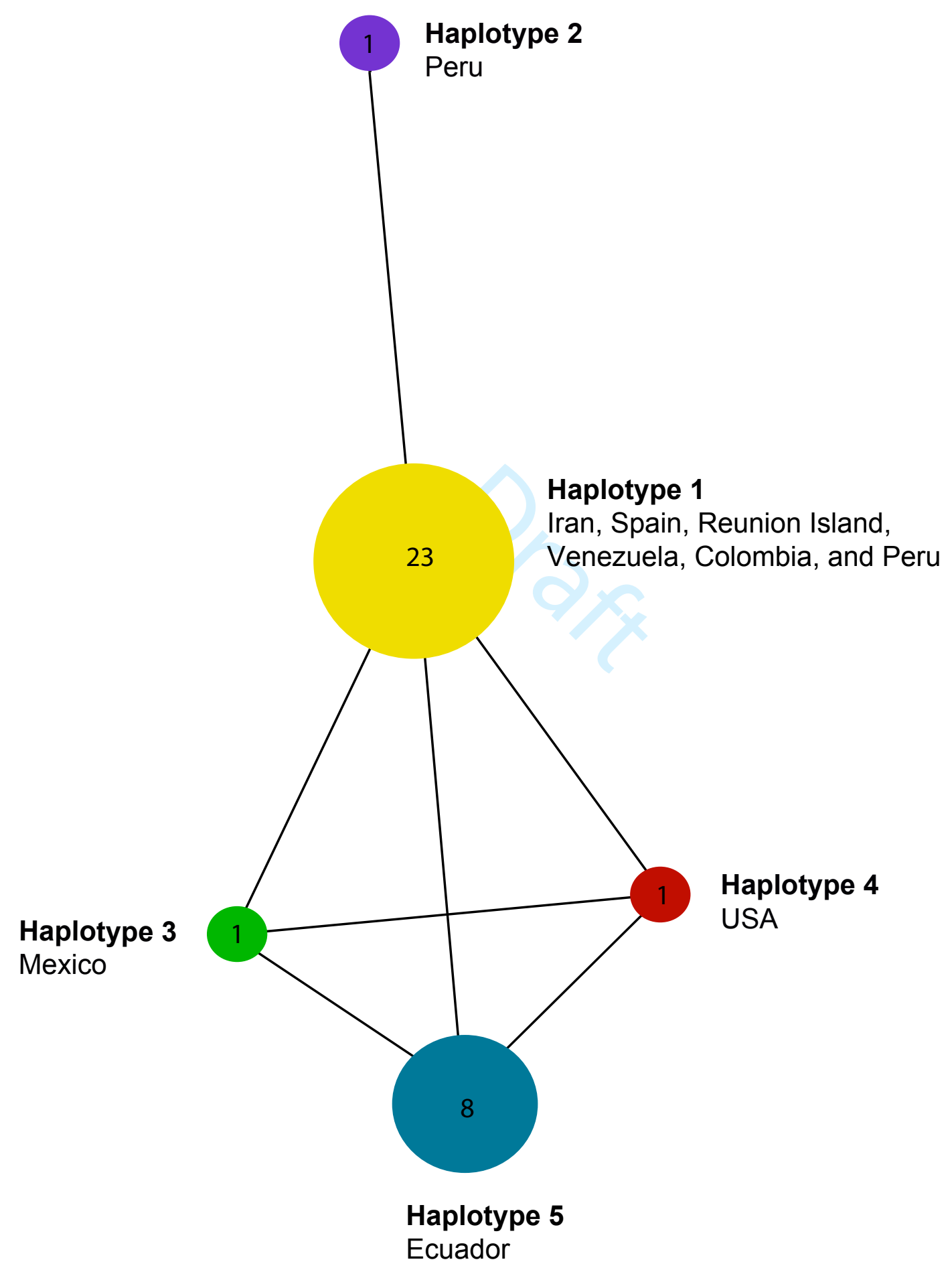

